\title{
Refleksja nad początkami wszechświata w traktacie Be-reszit Raba
}

\section{Wprowadzenie}

Aktualny wciąż problem źródeł wiedzy i sposobów jej zdobywania ma niezwykle bogatą, bo sięgającą starożytności, tradycję filozoficzną. Platon podzielił wiedzę na episteme i doxa, co było ugruntowane ontologicznie istnieniem sfery idei i rzeczy. I tak, według ucznia Sokratesa, nasza wiedza może być przeświadczeniem na temat świata widzialnego (doxa) lub po prostu wiedzą (episteme). ${ }^{1}$ Platon był natywistą i twierdził, że wiedza jest uzyskiwana lub zdobywana za pośrednictwem procesu anamnezy, czyli przypomnienia sobie tego, co dusza zapamiętała, przebywając $\mathrm{w}$ świecie idei. ${ }^{2}$ Wyraźnie dostrzegał on problem w rozróżnieniu doxa od episteme, wskazując, że źródłem episteme musi być idealny świat idei.

Jego uczeń Arystoteles nie poszedł śladami swojego mistrza i umieścił źródło poznania wiedzy w doświadczeniu — w kwestii genezy wiedzy był empirykiem. Jednakże koncepcję wiedzy budował na silnych założeniach racjonali-

Dr hab. InŻ. Mirostaw Rucki, prof. UTH Radom - Uniwersytet Technologiczno-Humanistyczny im. Kazimierza Pułaskiego w Radomiu, e-mail: m.rucki@uthrad.pl; mgr Micha£ Prończuk — Biblijne Towarzystwo Kreacjonistyczne, e-mail: Pronczuk@gmail.com.

(C) Copyright by Mirosław Rucki, Michał Prończuk \& Filozoficzne Aspekty Genezy.

${ }^{1}$ Ta idea została ujęta w słynnej alegorii jaskini (por. Platon, Państwo, przeł. Władysław Witwicki, Wydawnictwo ANTYK, Kęty 2003, VII, 514a-515d).

${ }^{2}$ Mowa o tym w dialogu Sokratesa z Fajdrosem (por. Platon, Dialogi, przeł. Władysław Witwicki, Tower Press, Gdańsk 2000, s. 18). 
stycznych. Tak więc, zdaniem Władysława Tatarkiewicza, „empiryczną drogą znajdować racjonalną wiedzę — to arystotelizm”. ${ }^{3}$ O rozróżnieniu między „poznaniem ze zmysłów” a „poznaniem wrodzonym” piszą także współcześnie Bryan Kolb oraz Ian Q. Whishaw:

Niektórzy filozofowie uważają, że wszystko, co wiemy, pochodzi ze zmysłów. To wydaje się całkiem rozsądne na początek. Wszelako wiadomo nam również, iż zmysły mogą nas zwodzić. $Z$ tego powodu inni filozofowie uważają, że musimy posiadać jakieś wrodzone poznanie świata, by odróżnić wrażenia rzeczywiste od wyimaginowanych. I to także wydaje się rozsądne. ${ }^{4}$

Z punktu widzenia dzisiejszej metodologii naukowej Biblia nie stanowi źródła wiedzy naukowej, przynajmniej w zakresie nauk przyrodniczych. Jej Autorzy — zarówno Boży, jak i ludzki ${ }^{5}$ — nie stawiali sobie za cel sporządzenia wyczerpującego opisu (modelu) jakichkolwiek zjawisk przyrodniczych. Przez wiele wieków teksty Biblii były jednak źródłem refleksji, w tym filozoficznej, nad początkiem istnienia wszechrzeczy. „Dopiero w czasach nowożytnych PierreSimon de Laplace na pytanie Napoleona, dlaczego w jego dziele o budowie Wszechświata nie ma żadnego odwołania do Boga, podobno odpowiedział: «Nie miałem potrzeby wprowadzenia takiej hipotezy»". ${ }^{6}$

Wspomniana refleksja, odwołująca się do Biblii, nie sprowadzała się jedynie do stwierdzenia, że Bóg tak urządził i tak ma być. Już starożytni autorzy żydowscy, a za nimi chrześcijańscy, zastanawiając się nad obserwowanym światem, sięgali do Biblii. Nie będąc podręcznikiem ani traktatem naukowym, Biblia była

\footnotetext{
${ }^{3}$ Władysław Tatarkiewicz, Historia filozofii, t. I, PWN, Warszawa 1978, s. 120.

${ }^{4}$ Bryan Kolb i Ian Q. Whishaw, Fundamentals of Human Neuropsychology, Freeman and Company, New York 1996, s. 99 (cyt. za: Jan WoleŃski, Epistemologia, PWN, Warszawa 2005, s. 413).

${ }^{5}$ Konstytucja dogmatyczna Dei Verbum (11) przyjmuje, że księgi biblijne „Boga mają za autora i jako takie zostały Kościołowi przekazane. Do sporzadzenia Ksiag świętych wybrał Bóg ludzi, którymi jako używającymi własnych zdolności i sił posłużył się, aby przy Jego działaniu w nich i przez nich, jako prawdziwi autorowie przekazali na piśmie to wszystko i tylko to, co On chciał" (por. Konstytucja dogmatyczna o Objawieniu Bożym DEI VERBUM, http://tiny.pl/g1n kd [26.06.2017]). Również dla myślicieli żydowskich, szczególnie w okresie powstawania traktatu Midrasz Raba, udział Boga w spisywaniu Tory był niekwestionowalny.
}

${ }^{6}$ Cyt. za: Augustus De Morgan, A Budget of Paradoxes, The Open Court Publishing Co., Chicago/London 1915, s. 2 (cyt. za: Andrzej ZABOŁotNY, „Naturalizm metodologiczny w nauce dylemat teisty", Filozoficzne Aspekty Genezy 2016, t. 13, s. 27 [25-48]). 
więc traktowana jako źródło wiedzy pochodzącej od Stwórcy — wiedzy, której nie można po prostu zignorować, mimo że teksty biblijne nie zawierają szczegółowych informacji przyrodoznawczych. Jednym z traktatów judaizmu, zawierającym — jak się wydaje — najwięcej refleksji na temat początków wszechświata, jest Midrasz Raba, komentarz do Pięcioksięgu Mojżeszowego, którego częścia jest midrasz do Księgi Rodzaju, ${ }^{7}$ określany po hebrajsku jako Be-reszit Raba ${ }^{8}$ Traktat w języku hebrajskim jest dostępny zarówno w wersjach współczesnych, ${ }^{9}$ jak i w postaci starodruków. ${ }^{10}$

\section{Traktat Be-reszit Raba}

W przedmowie do wydania angielskiego rabin Isidore Epstein, ${ }^{11}$ opisując początki midraszu jako metody egzegezy biblijnej w czasach Ezdrasza, ${ }^{12}$ podkreśla, że tekst czytanej Tory już w tamtych czasach nie miał punktów styczności z ówczesną myślą (naukową). I choć midrasz jako taki nie miał aspektów filozoficznych, a raczej praktyczny (zrozumienie i zastosowanie nakazów Tory w nowych warunkach życia kolejnych pokoleń), zawiera pewne elementy wyjaśniające, które są przedmiotem zainteresowania autorów niniejszego artykułu. $\mathrm{Z}$ drugiej strony charakter apologetyczny niektórych wypowiedzi jest zauważalny szczególnie w przypadku opowiadań o dyskusjach rabinów z filozofami pogańskimi.

\footnotetext{
${ }^{7}$ Księgi Mojżeszowe nazywane są po hebrajsku według pierwszego słowa poszczególnych ksiąg, stąd Księga Rodzaju nosi nazwę Be-reszit, bo jej pierwszym słowem jest „Na początku” (hebr. בראשית).

${ }^{8}$ Pisownię nazwy rozpatrywanego traktatu przyjmuję za Polskim Słownikiem Judaistycznym (por. Zofia Borzymińska, „Midrasz Raba”, w: Polski Słownik Judaistyczny, http://www.jhi. pl/psj/Midrasz_Raba [17.06.2017]).

${ }^{9}$ M.in. w Internecie: http://www.daat.co.il/daat/tanach/raba1/1.htm (22.06.2017).

${ }^{10}$ M.in. w postaci zdigitalizowanej wydania z 1566 roku: http://beta.hebrewbooks.org/11574 (22.06.2017).

${ }^{11} \mathrm{~W}$ kwestii dorobku naukowego rabina Isidore Epsteina por. np.: „Rabbi Dr. Isidore Epstein, B.A., Ph.D., D.Lit., 1894-1962”, Transactions (Jewish Historical Society of England) 1962 1967, vol. 21, s. 327-336.

${ }^{12}$ Por. Harry Freedman and Maurice Simon (eds.), Midrash Rabbah, vol. 1, The Soncino Press, London 1961, s. x.
} 
Be-reszit Raba należy do najstarszych tekstów typu midrasz i jest przypisywany rabinowi o imieniu Oszaja (Hoszaja) z pierwszego pokolenia autorów talmudycznych nazywanych amoraim, czyli amoraitów. ${ }^{13}$ Powstanie Be-reszit Ra$\boldsymbol{b} \boldsymbol{a}$ datuje się na czasy zamknięcia Talmudu Jerozolimskiego, ${ }^{14}$ czyli na drugą połowę czwartego wieku po Chrystusie. ${ }^{15} \mathrm{~W}$ tej epoce do gatunku egzegezy odwoływali się również chrześcijańscy pisarze posługujący się językiem aramejskim, z których najbardziej znanym jest św. Efrem Syryjski. ${ }^{16}$ Świadczy o tym nawet nazwa gatunku literackiego madrasza, w jakim tworzył, od rdzenia $d-r$-sz (hebr. דרש), tworzącego czasowniki „rozważać, rozprawiać, dyskutować, głosić".

W odróżnieniu od homiletycznych komentarzy typu midrasz, w Be-reszit $\boldsymbol{R} \boldsymbol{a} \boldsymbol{b} \boldsymbol{a}$ tekst biblijny komentowany jest werset po wersecie, a czasami słowo po słowie. Inne prace rabiniczne bowiem raczej skierowane były na kwestie przestrzegania micwot, przykazań judaizmu, i dlatego pomijały Księgę Rodzaju, która zawiera niewiele materiału halachicznego, czyli odnoszącego się do kwestii prawnych. Każdy rozdział Be-reszit Raba rozpoczyna się od wersetu z Księgi Rodzaju, po którym następują komentarze i opinie różnych rabinów, nieraz anonimowe, i tylko część wypowiedzi należy do właściwego autora dzieła.

We wprowadzeniu do wydania angielskiego ${ }^{17}$ podkreśla się, że rabini nie dążyli do zharmonizowania znaczenia tekstu biblijnego z wiedzą ściśle naukową, lecz szukali w zapisie Biblii przesłania odnoszącego się do ich bieżących problemów. Na przykład słowa „bezład i pustkowie” (Rdz 1,2) odnosili do Babilonii i Persji, a historię Jakuba i Ezawa wykorzystywali do snucia refleksji nad

\footnotetext{
${ }^{13}$ Aramejski wyraz amoraim (אמראים) oznaczający „mówców” lub „thumaczy”, jest odnoszony do mędrców Talmudu, działających w czasach od śmierci rabina Judy w 219 roku, aż do momentu ukończenia prac nad Talmudem Babilońskim, czyli około 500 roku. W Encyklopedii Żydowskiej rabin Oszaja jest wymieniany w pierwszym pokoleniu amoraitów palestyńskich (219279) jako Oszaja Starszy (por. Moses Mielziner, „Amora”, w: Isidore Singer, Frank Vizetelly, and Isaac Funk (eds.), The Jewish Encyclopedia, vol. 1-12, Funk \& Wagnals Co., New York - London 1901-1906, http://www.jewishencyclopedia.com/articles/1421-amora [29.04.2017]).

${ }^{14}$ Por. Freedman and Simon (eds.), Midrash Rabbah..., s. xxvii.

${ }^{15}$ Por. Moulie VIDAs, Tradition and the Formation of the Talmud, Princeton University Press, Princeton 2014, s. 50.

${ }^{16}$ Por. np. Przemysław TureK, Od Gilgamesza do kasydy. Poezja semicka w oryginale i w przekładzie, Księgarnia Akademicka, Kraków 2010, s. 178.

${ }^{17}$ Por. Freedman and Simon (eds.), Midrash Rabbah..., s. xxviii.
} 
walką Judei z Rzymem: Ezaw był dla nich symbolem potęgi Imperium Rzymskiego, które uciskało Żydów.

\section{Początek (Rdz 1,1)}

Jednym z poważnych problemów natury filozoficznej, podejmowanych przez rabinów, było pytanie o początek (hebr. ראשית). ${ }^{18}$ Dlaczego pierwszą litera pierwszego słowa pierwszej Księgi Tory nie jest pierwsza litera hebrajskiego alfabetu? Przecież Bóg jest tym, który od początku oznajmia, jaki będzie koniec wszechrzeczy (Iz 46,9-10), dlaczego więc Tora zaczyna się od litery bet (ב), drugiej w alfabecie hebrajskim? Jedna z przypowieści nawet głosi, że litera alef $(\aleph)$ uskarżała się przed Bogiem, z jakiego powodu nie została wybrana do celów stworzenia świata od samego początku, i w końcu Bóg miał się zgodzić, by ta litera rozpoczynała Dekalog (zdanie „Ja jestem Pan, Bóg twój...” zaczyna się od litery alef: אנכי [anochi]).

W midraszu Be-reszit Raba odnaleźć można wiele odpowiedzi na to pytanie. Przede wszystkim pojawia się koncepcja, że sama Tora była narzędziem stwórczym w rękach Boga (czyli istniała już przed stworzeniem świata). ${ }^{19}$ Uzasadnienie tej koncepcji jest następujące.

Kiedy król ziemski buduje pałac, nie czyni tego własną umiejętnością lub mądrością, tylko korzysta z pomocy architekta. Jednak architekt również nie buduje pałacu ,z głowy”, ale wcześniej przygotowuje plan, jak rozmieścić pokoje, przejścia i tym podobne. Taką rolę miała odegrać Tora, do której Bóg zaglądał, stwarzając świat. Słowo „początek” bowiem odnosi się do Tory: „Pan mnie stworzył, swe arcydzieło, jako początek swej mocy, od dawna" (Prz 8,22). Sta-

\footnotetext{
${ }^{18}$ Słowo reszit występuje w Biblii Hebrajskiej 51 razy (por. Gerhard Lisowsky (Hg.), Konkordanz zum Hebräischen Alten Testament, Deutsche Bibelgesselschaft, Stuttgart 1993). Słownik podaje cztery znaczenia: 1) co jest pierwsze, początek; 2) początek, punkt wyjściowy; 3 ) pierwszy i najlepszy; 4) pierwociny, najlepsza porcja (por. Ludwik KoEHLer, Walter BaumgarTner i Johann Jakub Sтамм, Wielki słownik hebrajsko-polski i aramejsko-polski Starego Testamentu, t. 2, Vocatio, Warszawa 2008, s. 224-225). W pierwszym wersecie Biblii jest w formie (bereszit) — „na początku”.

${ }^{19}$ Mędrcy Talmudu na podstawie tekstów biblijnych stwierdzili, że już przed stworzeniem świata istniało siedem rzeczywistości: Tora (Prz 8,22), pokuta (Ps 90,2-3), ogród Eden (Rdz 2,8), gehenna (Iz 30,33), Tron Chwały (Ps 93,2), Świątynia (Jr 17,12) oraz Imię Mesjasza (Ps 72,17) (Nedarim 39b; Pesachim 54a). Zagadnienie to również pojawia się w midraszu Be-reszit Raba.
} 
rożytność tego poglądu zdaje się potwierdzać sformułowanie znajdujące się w Księgach Machabejskich: „Stwórca świata, który ukształtował człowieka i wynalazł początek wszechrzeczy" (2Mch 7,23).

Według opinii rabina Abby ben Kahany ${ }^{20}$ Tora istniała wcześniej niż nawet Tron Chwały. Rabin Huna ${ }^{21}$ z kolei wyjaśniał, że już przed Torą powstał u Stwórcy zamiar stworzenia narodu izraelskiego: „Gdyby Święty, błogosławiony On, nie przewidywał, że po 26 pokoleniach ${ }^{22}$ Izrael otrzyma Torę, nie byłoby w niej napisane «Rozkaż synom Izraela»". Wyrażał też opinię, że celem stworzenia było późniejsze oddawanie dziesięciny, chały oraz pierwocin plonów, gdyż słowo ראשית (reszit) oznacza również pierwociny.

Przytoczono w midraszu kilka opinii rabinów, dotyczących „materiału budowlanego", z którego Bóg stwarzał świat. Stwierdzono, że jeśli ktokolwiek uważa, że świat był stwarzany z chaosu (tohu wabohu), poniża chwałę Bożą. Dowodem jest kolejność w opisie: najpierw zostały stworzone niebo i ziemia, a potem ziemia opisana jako pustkowie i chaos (tohu wabohu). ${ }^{23}$ Wyjaśnienie, jak Bóg stworzył niebo z „niczego", ${ }^{24}$ rabini znajdują w księdze proroka Izajasza: „On rozciągnął niebiosa jak tkaninę i rozpiął je jak namiot mieszkalny” $(40,22)$.

\footnotetext{
${ }^{20}$ Rabin ten jest tylko wymieniony na liście amoraitów palestyńskich, bez podania okresu działalności (por. „Tannaim and amoraim”, w: Singer, Vizetelly, and Funk (eds.), The Jewish Encyclopedia..., http://www.jewishencyclopedia.com/articles/14240-tannaim-and-amoraim [17.06. 2017]).

${ }^{21}$ Zapewne chodzi o rabina Hunę Bar Abbina ha-Kohena, nazywanego też Nehunia oraz Hunia, palestyńskiego amoraitę z pierwszej połowy IV wieku (por. Isidore SiNGER and Isaac BROYDÉ, „Huna Bar Abbin Ha-Kohen”, w: Singer, Vizetelly, and Funk (eds.), The Jewish Encyclopedia..., http://www.jewishencyclopedia.com/articles/7933-huna-bar-abbin-ha-kohen [17.06.2017].

${ }^{22}$ Według traktatu Pirke Awot $(5,2) 10$ pokoleń minęło od Adama do Noego i 10 od Noego do Abrahama (por. Pinchas Polonski (ed.), Sidur szaarej tfila, Machanaim, Jerusalem 2008, s. 299).

${ }^{23}$ Te dwa hebrajskie wyrazy oddawane są zazwyczaj w polskich przekładach Biblii jako „bezład” i ,pustkowie”.

${ }^{24} \mathrm{~W}$ kwestii wieloznacznego pojęcia „nicości” w myśli żydowskiej oraz rozumienia tego pojęcia por. np. Gershom SсHоlem, Mistycyzm żydowski i jego glówne kierunki, przeł. Ireneusz Kania, Wydawnictwo Aletheia, Warszawa 2007, s. 290.
} 
Przypowieść opowiada o pewnym filozofie próbującym zdyskredytować nauczanie Biblii i rabinów, który zadał pytanie rabinowi Gamalielowi: ${ }^{25}$ „Co za materiał miał wasz Bóg stwarzając świat? Tohu wabohu, ciemność, wodę, wiatr ${ }^{26}$ i przepaść”. Na to Gamaliel miał odpowiedzieć: „Biada temu człowiekowi!”, ponieważ każde z tych pojęć pojawia się w Piśmie Świętym jako wynik aktu stwarzania:

- Iz 45,7: „Ja [...] sprawiam pomyślność i stwarzam niedolę” (wyrazy רלע (szalom) - „pokój”, „wszechogarniająca harmonia” - oraz (ra) — „zło”, ,zły”, ,źle” — są tutaj, według Gamaliela, odpowiednikami chaosu i bezładu nazwanymi w Rdz 1,2 tohu wabohu);

- tamże: „Ja tworzę światło i stwarzam ciemności”;

- Ps 148,4-5: „Chwalcie Go, nieba najwyższe i wody [...], On bowiem nakazał i zostały stworzone";

- Am 4,6: „On to jest, który tworzy góry i stwarza wichry”;

- Prz 8,24: „Gdy jeszcze nie było przepaści, spłodzonam jest” (Biblia Gdańska). ${ }^{27}$

Wyjątkowość Objawienia dotyczącego stworzenia świata na tle wszelkich innych koncepcji ,początku” wyraził rabin Joszua z miasta Siknin. ${ }^{28}$ Zadał on pytanie: dlaczego Bóg nie objawił innym narodom prawdy o tym, co było stworzone w ciągu pierwszych sześciu dni? Według niego stało się tak, by Izrael nie mógł być posądzony o kradzież wiedzy, jaką zdobyły inne narody. Miałby o tym świadczyć tekst Psalmu 111,6: „Ludowi swemu okazał potęgę dzieł swoich, oddając im posiadłości pogan". Rabin Jona ${ }^{29}$ mówił w imieniu rabina Lewiego: ${ }^{30}$ „Dlaczego świat został stworzony od litery bet? Dlatego, że bet jest zamknięty

${ }^{25}$ Wśród wybitnych rabinów kilku nosiło to imię; jednym z najbardziej znanych był Rabban Gamaliel (zm. ok. 70 r. po Chr.), wnuk Hillela Wielkiego, nauczyciel Szaula z Tarsu - św. Pawła (Dz 22,3). Według przekazów zajmował stanowisko przywódcy Sanhedrynu przez około 10 lat przed zburzeniem Świątyni przez Rzymian.

${ }^{26}$ Pojawiające się w opisie stworzenia (Rdz 1,2) słowo רוח (ruach) thumaczy się na polski jako Duch [Boży].

${ }^{27}$ Biblia Hebrajska zawiera tutaj wyraz תהמות (tehomot) — ,głębiny”, który w Biblii Tysiąclecia w tym miejscu jest tłumaczony jako „ocean”, ale w Rdz 1,2 jako „przepaść”.

${ }^{28}$ Niewielka miejscowość położona w Galilei na północ od Jotapaty. 
$\mathrm{z}$ [trzech] stron, ale otwarty z przodu, zatem nie wolno dociekać, co jest nad i pod, co jest przed i za [tym]". Tosefta (uzupełnienie) do traktatu talmudycznego Chagiga 2a wyjaśnia, że ograniczenie dotyczy zarówno czasu, jak i przestrzeni. Rabin Szymon Bar Kappara ${ }^{31}$ skojarzył to zagadnienie $\mathrm{z}$ wersetem z Księgi Powtórzonego Prawa (Pwt 4,32): „Zapytaj no dawnych czasów, które były przed tobą, zaczynając od dnia, w którym Bóg stworzył człowieka na ziemi” i twierdził: „Możesz spekulować tylko [na temat tego, co się wydarzyło] od dnia, kiedy dni zostały stworzone, ale nie możesz spekulować o tym, co było przedtem". Rabin Chama ben Chanina ${ }^{32}$ wyrażał przekonanie, że Tora istniejaca przed stworzeniem świata zawiera wiedzę na ten temat, lecz ludzie nie powinni jej poznawać.

Oczywiście jest cały szereg innych wyjaśnień, dlaczego Tora (czyli akt Stworzenia) zaczyna się od litery bet, a nie alef. Na przykład dlatego, że słowo „błogosławieństwo” zaczyna się od litery bet, a „przekleństwo” — od litery alef, co dyskwalifikowało tę ostatnią ze stanowiska pierwszej litery Tory. W ten sposób miał być obalony możliwy zarzut, że Tora jakoby przynosi przekleństwo.

Inne ciekawe wyjaśnienie wskazuje na skromność Boga. Rabin Jehuda wyrażał opinię, ${ }^{33}$ że królowie ludzcy w swojej pysze najpierw domagają się za-

${ }^{29}$ Rabin Jona był jednym z największych autorytetów rabinicznych czwartej generacji amoraitów (IV w.). Uważano go za jednego z „mocarzy ziemi Izraela” (por. Solomon Schechter and S. Mendelsohn, „Jonah”, w: Singer, Vizetelly, and Funk (eds.), The Jewish Encyclopedia..., http://www.jewishencyclopedia.com/articles/8752-jonah [26.06.2017]).

${ }^{30}$ Prawdopodobnie Levi II, amoraita palestyński trzeciej generacji (por. Solomon SchechteR and S. Mendelsohn, „Levi II”, w: Singer, Vizetelly, and Funk (eds.), The Jewish Encyclopedia..., http://www.jewishencyclopedia.com/articles/9803-levi-ii [26.06.2017]).

${ }^{31}$ Prawdziwym imieniem rabina Szymona Bar Kappary, najczęściej nazywanego po prostu Bar Kappara (lub po hebrajsku Ben ha-Kappar), było Eleazar ben Eleazar ha-Kappar. Był uczniem Jehudy ha-Nasiego i należał do grona rabinów stanowiących ogniwo przejściowe między tannaitami a amoraitami (por. „Bar Kappara”, w: Singer, Vizetelly, and Funk (eds.), The Jewish Encyclopedia..., http:/www.jewishencyclopedia.com/articles/13703-simeon-bar-kappara [26.06. 2017]).

${ }^{32}$ Rabin Chama ben Chanina, wymieniany w midraszu Be-reszit Raba, należał do amoraitów palestyńskich III wieku i był przewodniczacym szkoły rabinicznej w Seforis, tak samo jak jego ojciec rabin Chanina bar Chama (zm. ok. 250 r.) (por. „Hama b. Hanina”, w: Singer, Vizetelly, and Funk (eds.), The Jewish Encyclopedia..., http://www.jewishencyclopedia.com/articles/7119hama-b-hanina [26.06.2017]).

${ }^{33}$ Por. Freedman and Simon (eds.), Midrash Rabbah..., s. 11-12. 
szczytu, zanim cokolwiek uczynią dla ludu, i wszystkie inskrypcje zaczynają od swego własnego imienia. Bóg natomiast ujawnił jedno ze swoich imion (אלהים) (Elohim - zaczynające się od alef) dopiero po tym, jak utworzył fundamenty przeznaczonego dla ludzi wszechświata.

W midraszu Be-reszit Raba wiele uwagi poświęcono kwestii kolejności stwarzania nieba i ziemi. Oba wyrazy: „niebo” i „ziemia” są użyte w Księdze Rodzaju (Rdz 1,1) z rodzajnikami określonymi (ה), co oznaczałoby konkretnie to niebo i konkretnie tę ziemię, którą Bóg zaplanował stworzyć. Rabini, porównując akt stworzenia do budowli ludzkich, zauważają, że ludzie raczej najpierw budują główny gmach i rozbudowują go, jeśli im wyjdzie dobrze (lub zmniejszają, jeśli nie wychodzi zgodnie $\mathrm{z}$ planem). Bóg natomiast najpierw stworzył otoczenie Ziemi, a potem samą Ziemię dokładnie zgodnie ze swoim pierwotnym zamiarem, niczego nie zmieniając.

Jednakże kolejność stwarzania nieba i ziemi była dyskutowana przez uczniów Hillela i Szammaja: ${ }^{34}$ pierwszy uważał bowiem, że ziemia została stworzona najpierw, i odwoływał się do wersetu Rdz 2,4: „Gdy Pan Bóg uczynił ziemię i niebo...". Szammaj natomiast uważał, że niebo jako tron Boga (Iz 46,1) musiało być stworzone najpierw. Rabin Jehuda ben Ilaj ${ }^{35}$ popierał opinię Hillela, argumentując, że słowa Psalmu 102,26 potwierdzają taką kolejność wydarzeń: „Ty niegdyś założyłeś ziemię i niebo jest dziełem rąk Twoich”. Rabin Johanan, usiłując zharmonizować te sprzeczne opinie, stwierdził: „Co do stworzenia, niebo było najpierw, ale co do ukończenia, ziemia była wcześniej [ukończona]". Podobnie rabin Symeon wyrażał zdziwienie, o co mędrcy kruszą kopie, kiedy przecież niebo i ziemia zostały stworzone jednocześnie: „Moja to ręka za-

\footnotetext{
${ }^{34}$ Hillel i Szammaj byli przewodniczącymi Sanhedrynu w czasach Heroda Wielkiego (koniec I w. przed Chr.). Obaj należeli do stronnictwa faryzeuszów, ale ich poglądy diametralnie różniły się w ponad trzystu kwestiach dotyczących prawa żydowskiego. Zapoczątkowane przez nich dyskusje kontynuowali ich uczniowie (por. Joseph JaCoBs and Jacob Zallel LauterBaCH, „Zugot”, w: Singer, Vizetelly, and Funk (eds.), The Jewish Encyclopedia..., http://www.jewishencyclopedia. com/articles/15293-zugot [26.06.2017]).

${ }^{35}$ Rabin Jehuda ben Ilaj był jednym z najważniejszych tannaim II wieku. Otrzymał ordynację rabiniczną w czasach prześladowań ze strony Rzymu, dlatego musiał się ukrywać. W interpretacji tekstów biblijnych korzystał z metody swojego mistrza rabina Akiby (por. Isidore Singer and Jacob Zallel Lauterbach, „Judah Ben Ilai”, w: Singer, Vizetelly, and Funk (eds.), The Jewish Encyclopedia..., http://www.jewishencyclopedia.com/articles/8994-judah-ben-ilai [26.06.2017]).
} 
łożyła ziemię i moja prawica rozciągnęła niebo. Gdy na nie zawołam, stawią się natychmiast [jednocześnie]" (Iz 48,13).

W dyskusjach spisanych w traktacie Be-reszit Raba zauważa się również, że światło zostało stworzone wcześniej niż Słońce i Księżyc. Rabini nie usiłowali jednak poprawiać lub „naciągać” tekstu objawionego do oczywistych, obserwowalnych faktów przyrodniczych, ale wprowadzili rozróżnienie między światłem naturalnym a światłem nadprzyrodzonym. Zanim zostało stworzone Słońce jako podstawowe źródło światła, Bóg oświetlał wszystko własnym światłem, które zostało „schowane” po pojawieniu się Słońca. Według rabinów ujawnienie tego światła Bożego nastąpi w chwili przyjścia Mesjasza.

Inną „nieścisłością” tekstu biblijnego, dostrzeżoną przez rabinów, jest użycie słowa ,jeden” w wersecie piątym Księgi Rodzaju, tłumaczonym zazwyczaj jako „dzień pierwszy”. Rabin Samuel ben Ammi ${ }^{36}$ zastanawia się, dlaczego odliczanie dni nie jest według normalnego porządku ,jeden, dwa, trzy” lub ,pierwszy, drugi, trzeci”, tylko ,jeden, drugi, trzeci”. Wyjaśnia to w taki sposób, że Bóg w tym dniu był absolutnie sam i bardzo pragnął nawiązania relacji z człowiekiem, którego dopiero miał zamiar stworzyć. Dlatego też dzień ten został później dziesięciokrotnie uhonorowany w Torze, między innymi ze względu na ofiary składane w Świątyni, kapłaństwo, królów i książąt Izraela. Z kolei izraelski kosmolog Gerald Schroeder znalazł w pismach rabina Nachmanidesa ${ }^{37}$ (XIII w.) ciekawe spostrzeżenie dotyczące definicji układu odniesienia w opowieści o stworzeniu świata: „Pierwszy” jest w porównaniu do innych, a określenie ,jeden” jest absolutne. Nachmanides thumaczy, że w „Dniu Jeden” został stworzony czas. ${ }^{38}$

Obecnie, wziąwszy pod uwagę dobrze potwierdzone dane naukowe, wydaje się, że opis ten jest bardzo bliski rzeczywistości kosmicznej odkrywanej i opisy-

\footnotetext{
${ }^{36}$ Samuel Ben Ammi należał do amoraitów palestyńskich początku IV wieku (por. Wilhelm BACHER and Schulim Ochser, „Samuel Ben Ammi”, w: Singer, Vizetelly, and FunK (eds.), The Jewish Encyclopedia..., http://www.jewishencyclopedia.com/articles/13091-samuel-ben-ammi [26.06.2017]).

${ }^{37}$ Rabin Mosze ben Nachman (1194-1270) — kabalista, wybitny komentator Tory i Talmudu (por. „Moses Ben Naḥman Gerondi”, w: Singer, Vizetelly, and Funk (eds.), The Jewish Encyclopedia..., http://www.jewishencyclopedia.com/articles/11284-nahmanides-moses [26.06.2017]).

${ }^{38}$ Por. Gerald Schroeder, „Age of the Universe”, http://www.aish.com/societywork/science nature/Age_of_the_Universe.asp (29.04.2017).
} 
wanej metodami naukowymi. ${ }^{39}$ Stephen Hawking utrzymuje, że „Wszechświat i czas jako taki miały swój początek w Wielkim Wybuchu". ${ }^{40}$ Roger Penrose twierdzi: „Czas i przestrzeń nie mogą być rozważane oddzielnie, lecz są jedynie szczególnymi aspektami łączącej je «czasoprzestrzeni»». ${ }^{41}$ Zbigniew Treppa pisze o odcinku czasu rzędu „10 $10^{-43}$ sekundy po Wielkim Wybuchu. Wtedy to właśnie zaistniał czas i przestrzeń, materia, energia, oddziaływania". ${ }^{42}$ Zbliżona do tych ustaleń naukowych koncepcja nierozłącznej czasoprzestrzeni, zauważalna w rozważaniach rabinów, zapewne ma swoje źródła w samej warstwie językowej, gdyż hebrajski wyraz olam (עולם) ${ }^{43}$ oznacza jednocześnie wszechświat jako przestrzeń i wieczność jako przestrzeń czasową między początkiem i końcem istnienia świata materialnego.

Jako ciekawostkę można odnotować fakt, że spekulacje rabiniczne wokół opisu stworzenia wygenerowały koncepcję, której autorstwo przypisuje sobie Hawking. W jednym z wykładów stwierdza on:

Chodzi o to, że najbardziej prawdopodobna historia powstawania Wszechświata przypomina powierzchnię, na której tworzą się bąbelki. Wiele bąbelków się pojawia i znika. To odpowiada [pojawianiu się] wielu wszechświatów, które zaczynają się rozszerzać, ale potem ulegają zniszczeniu, wciąż będąc mikroskopijnych rozmiarów. Potencjalnie są alternatywnymi wszechświatami, ale nie stanowią przedmiotu zainteresowania, ponieważ nie istnieją wystarczająco długo, by rozwinąć galaktyki i gwiazdy, nie mówiąc już o inteligentnej formie życia. Niektóre z tych bąbelków jednak rozrastają się do określonych rozmiarów zapewniających bezpieczne trwanie. Będą powiększać się coraz bardziej, tworząc bąbelki widoczne gołym okiem. Te bąbelki odpowiadają

\footnotetext{
${ }^{39}$ Więcej na ten temat w artykule: Mirosław RucKI, „Sześć dni stworzenia - Heksaemeron”, Teologia i Człowiek 2016, nr 1 (33), s. 85-105.

${ }^{40}$ Stephen HawkING, „The Beginning of Time”, http://www.hawking.org.uk/the-beginning-oftime.html (29.04.2017).

${ }^{41}$ Roger Penrose, Droga do rzeczywistości. Wyczerpujący przewodnik o prawach rządzących Wszechświatem, przeł. Jerzy Przystawa, Prószyński i S-ka, Warszawa 2006, s. 589.

${ }^{42}$ Zbigniew TRePpa, Fotografia z Manopello. Twarz Zmartwychwstającego Mesjasza, Wydawnictwo Duszpasterstwa Rolników, Włocławek 2009, s. 16.

${ }^{43}$ To samo dotyczy powszechnie używanego w czasach talmudycznych języka aramejskiego. Marcus Jastrow podaje jako znaczenie wyrazu עלם (olam) jednocześnie eternity, world (,wieczność”, „Świat”), gdyż często rozróżnienie tych dwóch znaczeń w pismach rabinicznych jest praktycznie niemożliwe (por. Marcus JASTROw, A Dictionary of the Targumim, the Talmud Babli and Yerushalmi, and the Midrashic Literature, vol. 2, Luzac \& Co, London 1903, s. 1084).
} 
wszechświatom, które mogą rozszerzać się coraz bardziej. To zjawisko nazywane jest inflacją, tak samo jak coroczny wzrost cen. ${ }^{44}$

W traktacie Be-reszit Raba wymieniona jest opinia rabina Abbahu, ${ }^{45}$ który uważał, że nadejście wieczoru pierwszego dnia stworzenia sugeruje istnienie wcześniejszego porządku czasowego. $\mathrm{Z}$ tego wyprowadzał on twierdzenie, że Bóg stwarzał wszechświaty i niszczył je, aż w końcu udało Mu się stworzyć aktualny świat. „Ten świat mi się podoba, a tamte się nie podobają” (parafraza Rdz $1,31)$ - orzekł Bóg i pozostawił nasz wszechświat, w którym zostaliśmy stworzeni.

Z powodów zrozumiałych, wobec niewielkiej wiedzy i małej wartości praktycznej, „spekulacje techniczne” dotyczące konstrukcji wszechświata, a szczególnie nieba, zajmują mało miejsca i są raczej fantazjami. Bazując na jednym lub dwóch słowach, rabini rozważają warstwową strukturę nieba, grubość poszczególnych warstw i sposób utrzymania na nich Słońca, Księżyca i gwiazd. Godny odnotowania jest fakt, że w tych spekulacjach praktycznie nie ma odniesienia do obszernej wiedzy astronomicznej, zdobytej ówcześnie przez Babilończyków. ${ }^{46}$

\section{Stworzenie czlowieka}

Komentując stworzenie człowieka (Rdz 1,26nn), rabin Johanan ${ }^{47}$ odniósł się do Ps 139,5, wnioskując, że Bóg, stwarzając człowieka, od początku przeznaczył go do życia „w tym świecie” i „świecie przyszłym”, czyli do życia

\footnotetext{
${ }^{44}$ Stephen HawkING, „The Origin of the Universe”, http://www.hawking.org.uk/the-origin-ofthe-universe.html (29.04.2017).

${ }^{45}$ Por. Freedman and Simon (eds.), Midrash Rabbah..., s. 64. O życiu rabina Abbahu nie zachowały się informacje; z dyskusji wynika, że mógł należeć do amoraitów palestyńskich.

${ }^{46}$ Maciej Popko podaje, że już w IV wieku przed Chrystusem w Babilonii dokonywano obliczeń astronomicznych z dokładnością, jaka została osiągnięta w Europie dopiero w czasach nowożytnych (por. Maciej Popкo, „Wschód starożytny a początki myśli europejskiej”, Przegląd Orientalistyczny 1999, nr 1-2 (189-190), s. 15-25).

${ }^{47}$ Por. Freedman and Simon (eds.), Midrash Rabbah..., s. 54.
} 
wiecznego po zmartwychwstaniu. ${ }^{48}$ Rabin Berekia ${ }^{49}$ sugerował z kolei, że Bóg, stwarzając pierwszego człowieka, Adama, przewidywał, że część jego potomków będzie sprawiedliwych, a część nieprawych. Na podstawie Ps 1,6 doszedł do wniosku, że Bóg usunął sprzed siebie wizję tych niesprawiedliwych, ignorując ich, i w miłosierdziu stworzył pierwszego człowieka. ${ }^{50}$ Według innej interpretacji Bóg ukrył wiedze o przyszłych niesprawiedliwych przed aniołami, którzy byli obecni przy stwarzaniu świata. Wniosek z tych rozważań jest taki, że gdyby Bóg rozważył dobroć i niegodziwość przyszłych pokoleń, Jego sędziowska sprawiedliwość nie pozwoliłaby Mu na stworzenie człowieka.

Bazując na wersecie Ps 85,2 , rabini utworzyli rozbudowany midrasz dotyczący dyskusji aniołów wokół zagadnienia, czy człowiek ma być stworzony, czy nie. ${ }^{51}$ Argumentem miłości było to, że człowiek będzie kochał i okazywał miłosierdzie, ale prawda ${ }^{52}$ wysuwała kontrargument, że człowiek będzie kłamał, nie warto zatem go stwarzać. Z kolei sprawiedliwość argumentowała, że stworzony człowiek będzie postępować sprawiedliwie, należy więc go stworzyć, ale pokój oponował, że będzie jednak miał zamiłowanie do przemocy, nie trzeba zatem go stwarzać. Rabin Huna Starszy z Seforis ${ }^{53}$ uważał, że Bóg stworzył człowieka, podczas gdy aniołowie się spierali, i postawił ich ostatecznie przed faktem dokonanym.

Stworzenie człowieka zostało uznane przez Boga za „bardzo dobre” (Rdz 1,31), co rabini Pinchas ${ }^{54}$ i Chilkia ${ }^{55}$ uzasadniają na podstawie podobieństwa

\footnotetext{
${ }^{48}$ Hebrajskie słowa צרתני וקדם אחור są thumaczone na polski jako „Ty ogarniasz mnie zewsząd i kładziesz na mnie swą rękę”, rabini jednak rozumieją צרת jako „ukształtowałeś mnie”, וקדם אחור jako ,przed i po” albo „wcześniej i później”.

${ }^{49}$ Zapewne rabin Berekia I, amoraita palestyński z III wieku (por. Marcus JASTROW and S. Mendelsohn, „Berechiah I”, w: Singer, Vizetelly, and Funk (eds.), The Jewish Encyclopedia..., http://www.jewishencyclopedia.com/articles/3036-berechiah-i-r [26.06.2017]).

${ }^{50}$ Słowa Psalmu „Pan uznaje drogę sprawiedliwych, a droga występnych zaginie” są w tej dyskusji rozumiane jako „Bóg usunął ją sprzed oczu”.

${ }^{51}$ Słowa Psalmu „Laskawość i wierność spotkają (נפגשו) się z sobą, ucałują się (נשקו) sprawiedliwość i pokój" są rozumiane wręcz jako zbrojne starcie aniołów reprezentujących Miłosierdzie i Prawdę oraz Sprawiedliwość i Pokój.

${ }^{52}$ Słowo אמת (emet) może oznaczać zarówno ,wierność”, jak i „prawdę”.

${ }^{53}$ Por. Freedman and Simon (eds.), Midrash Rabbah..., s. 58.
} 
słów „człowiek” (אדם - adam) i „bardzo” (מאד - meod), składających się z tych samych spółgłosek: alef, dalet, mem.

Jedną z ważniejszych cech człowieka, wyeksponowanych przez rabinów, jest wolna wola, nawet w popełnianiu grzechów, między innymi bałwochwalstwa. Autor midraszu opowiada, że kiedy Mojżesz spisywał teksty Tory na Synaju, doszedł do słów „Rzekł Bóg: uczyńmy człowieka” (Rdz 1,26) i zapytał: „Panie wszechświata! Po co [mówisz w liczbie mnogiej], stwarzając podstawy dla wielobóstwa?”. Na co Bóg miał odpowiedzieć: „Napisz, [jak powiedziałem], a kto chce błądzić, niech błądzi”.

Rabini wskazują również na cztery cechy „anielskie” i cztery „zwierzęce”, które są charakterystyczne dla człowieka. Do aniołów człowieka upodabnia: postawa stojąca (jak u posługujących aniołów), mowa, rozumienie i widzenie. ${ }^{56}$ Do zwierząt natomiast człowieka upodabniają cztery cechy: człowiek musi jeść i pić, rozmnażać się, wypróżniać się, w końcu zaś umiera tak samo jak zwierzę. Rabin Tifdaj ${ }^{57}$ wkłada w usta Boga słowa: „Jeśli stworzę człowieka tylko z elementów duchowych, będzie żył [wiecznie] i nie umrze, ale jeśli stworzę go tylko z elementów ziemskich, umrze i nie będzie żył. Stworzę więc [człowieka] z elementów górnych [duchowych] i dolnych [materialnych]: jeśli zgrzeszy umrze, jeśli nie zgrzeszy — będzie żył".

Interesujący temat jest poruszany w związku ze słowami Boga: „Wszystko było bardzo dobre". Pojawia się pytanie o to, czy takie rzeczy jak śmierć, cierpienie czy złe skłonności mogą być uważane za dobre. Odpowiedź, jaką proponują rabini, z reguły odnosi się do życia wiecznego w przyszłym świecie. Na przykład cierpienie jest dobre, ponieważ prowadzi do oczyszczenia i pokuty,

\footnotetext{
${ }^{54}$ Najprawdopodobniej jest to Pinchas ben Jair, tanna czwartego pokolenia, który działał w drugiej połowie drugiego stulecia. Przypisywano mu wiele cudów, między innymi chodzenie po wodzie (por. Wilhelm Bacher and Isaac Broydé, „Phinehas Ben Jair”, w: Singer, Vizetelly, and FunK (eds.), The Jewish Encyclopedia..., http://www.jewishencyclopedia.com/articles/12121phinehas-ben-jair [26.06.2017]).

${ }^{55}$ Por. Freedman and Simon (eds.), Midrash Rabbah..., s. 58. Rabin Chilkia najprawdopodobniej należał do amoraitów babilońskich.

${ }^{56}$ Autor komentarza wyjaśnia, że w odróżnieniu od zwierząt człowiek może zmieniać kąt patrzenia, obracając gałkami ocznymi, bez poruszania głową.

${ }^{57}$ Rabin Tifdaj wymieniany jest tylko w tym miejscu traktatu (por. Freedman and Simon (eds.), Midrash Rabbah..., s. 61-62).
} 
czyli ostatecznie do życia wiecznego. Nawet w śmierci rabini dopatrzyli się dobra: dla sprawiedliwego bowiem jest ona gwarancją podwójnej nagrody w życiu przyszłym - jedną sprawiedliwy otrzyma za swoje prawe uczynki, a drugą za to, że zaznał śmierci, na którą nie zasługiwał. Ponadto śmierć jest odpoczynkiem dla sprawiedliwego, który musi całe życie zmagać się, stawiając czoła swoim złym skłonnościom i niegodziwości złych ludzi.

Widzimy zatem, że refleksja dotycząca stworzenia człowieka nieuchronnie prowadzi do pytania o wolę. Większość słowników wolę definiuje jako świadome i celowe regulowanie swego postępowania. Wola to również dyspozycja psychiczna człowieka do świadomego i celowego regulowania swego postępowania, do podejmowania decyzji i wysiłków w celu realizacji pewnych działań, przyjęcia pewnych postaw. ${ }^{58}$ Trochę inną definicję woli podaje Leksykon biblijny. Słowa „wola” oraz „chcieć” oddają różne pojęcia hebrajskie i greckie, które w języku hebrajskim oznaczają nie tyle decyzję, ile działanie. Słowo „chcieć” thumaczy często jedną z form czasownika hebrajskiego, która oznacza raczej „uczynić” lub „kontynuować”. ${ }^{59}$

Definicje te mówią przede wszystkim o dwóch aspektach woli: świadomości i celowości. Nie uwzględniają one problemu pochodzenia aktów woli ani tego, czy akty te są wolne, czy zależne. Odpowiedzi na te pytania usiłują znaleźć filozofowie czy kognitywiści, podczas gdy rabini dostrzegają pochodzenie woli człowieka bezpośrednio w akcie stworzenia ludzkiej istoty „na obraz i podobieństwo Boga".

\section{Ukończenie i odpoczynek}

Ukończenie dzieła stworzenia również stanowiło dla rabinów przedmiot refleksji, nie tylko halachicznej, ale też filozoficznej. Ich uwagę przyciągnęło między innymi zdanie: „A gdy Bóg ukończył w dniu szóstym swe dzieło, nad którym pracował, odpoczął dnia siódmego po całym swym trudzie, jaki podjął" $(\operatorname{Rdz} 2,2)$.

\footnotetext{
${ }^{58}$ Por. Krystyna DŁugosz-Kurczabowa, Wielki slownik etymologiczno-historyczny języka polskiego, PWN, Warszawa 2008, s. 725.

${ }^{59}$ Por. Fritz Rienecker i Gerhard MaIER, Leksykon biblijny, przeł. Danuta Irmińska, Vocatio, Warszawa 2001, s. 864.
} 
Typowo halachicznym problemem rabinów było określenie początku soboty jako dnia odpoczynku, czyli chwili, po której już nie wolno Żydom wykonywać żadnej pracy. W swoich rozważaniach mędrcy uznali, że Bóg jako Stwórca i Pan wszechrzeczy (w tym czasu) z pewnością był w stanie zidentyfikować moment, który jeszcze należał do dnia szóstego, i moment następny, który już należał do szabatu. Obrazowo granice między tymi dwoma momentami rabini przedstawiają jako barierę „grubości włoska”. W pewnym sensie rabini mieli rację, że taką granicę między poszczególnymi chwilami w ogóle da się wyodrębnić. Dzisiejsza fizyka definiuje najkrótszy odstęp czasu, nazywany czasem Plancka, jako:

$$
t_{\mathrm{P}}=5,39116(13) \times 10^{-44} \mathrm{~s}
$$

a upływ czasu traktuje jako przeskoki od jednej chwili $t_{\mathrm{P}}$ do drugiej. ${ }^{60}$

Odcinek czasu krótszy od czasu Plancka nie ma sensu fizycznego, stąd można uznać, że taka jest właśnie granica (odstęp) między poszczególnymi chwilami obserwowanego przez nas czasu. Kosmologia kwantowa odnosi się do czasu i przestrzeni powyżej wymiarów (jednostek) Plancka. Fizycy kwantowi otwarcie przyznają, że przed osiągnięciem przez wszechświat wymiarów Plancka, w chwili równej stałej Plancka, rozwojem wszechświata mógł kierować Bóg stwarzający wszystko z „niczego”. ${ }^{61}$ Taki odcinek jak stała Plancka (czy jak włosek według definicji rabinów) jest o wiele za krótki jak na ludzkie możliwości percepcji, dlatego też rabini dochodzą do wniosku, że Żydzi muszą „,dodać czas nieświęty do świętego". Innymi słowy, rozpoczęcie obchodów szabatu jakiś czas przed rzeczywistym rozpoczęciem siódmego dnia jest konieczne, by nie złamać przykazania o przestrzeganiu szabatu przez przekroczenie tej niezauważalnej dla człowieka granicy między piątkiem a sobotą.

Ważnym zadaniem z punktu widzenia wypełniania przykazań sformułowanych w Torze było określenie pojęcia ,praca”, gdyż nie wolno jej było wykonywać w szabat. Wbrew pozorom nie stanowiło to łatwego zadania i niejedna dyskusja $\mathrm{w}$ środowisku rabinicznym była na ten temat przeprowadzona. Autorzy traktatu Be-reszit Raba odnoszą się do tego zagadnienia, zastanawiając się nad tym, czy Bóg rzeczywiście tak się utrudził, że musiał odpoczywać. Rabin Bere-

\footnotetext{
${ }^{60}$ Por. Jonathan Sumber, On the Nature and Origin of Time, Space, Gravity and Reality, Outskirts Press, Denver 2016, s. 20.

${ }^{61}$ Por. Rem Edwards, What Caused the Big Bang?, Brill, Amsterdam - New York 2001, s. 4.
} 
kia ${ }^{62}$ wyrażał opinię, że Bóg uczynił wszystko bez wysiłku i trudu, ale słowa „dzieło, nad którym pracował” są napisane ze względu na ukaranie ludzi, którzy będą niszczyć „stworzony z trudem” świat, i nagrodę dla sprawiedliwych, którzy własną pracą ulepszają powierzony sobie przez Boga świat. Przywołując werset Wj 20,11, rabin Lewi wyjaśnia: „Póki ręce Pana pracowały nad [światem], on się powiększał; ale kiedy ręce Pana spoczęły, spoczynek został udzielony [stworzeniu]”. W tym miejscu Lewi interpretuje słowo ישבת ,odpoczął” jako „stworzył odpoczynek”.

Tekst hebrajski Biblii, szczególnie niektóre rękopisy, sugeruje, że dzieło stworzenia zostało ukończone w dniu siódmym, a nie szóstym. Autor traktatu $\boldsymbol{B e}$-reszit Raba usiłuje wyjaśnić to, przytaczając opinie różnych rabinów, że szabat, będąc ukoronowaniem stworzenia, sam z siebie stanowił jego element. Rabini, porównując Boga do króla budującego pałac dla panny młodej, mówili: „Czego brakowało po ukończeniu pałacu? Panny młodej! Podobnie czego brakowało światu [po ukończeniu stworzenia]? Szabatu!”. Zatem właśnie szabat i jego odpoczynek, niebędący przecież aktem stworzenia, jest uzupełnieniem tegoż stworzenia, bez którego nie ma ono sensu. Dlatego wielokrotnie w obchodach soboty podkreśla się, że ona jest królową ${ }^{63}$ i oblubienicą. ${ }^{64}$

\section{Podsumowanie}

Zastanawiając się nad początkami świata, rabini byli świadomi własnych ograniczeń. Wiele zjawisk otaczającego świata było dla nich niezrozumiałych. W midraszu Be-reszit Raba odnotowane są słowa rabina Huny: „Jeśli nie jesteś w stanie pojąć natury błyskawicy, to jak możesz pojąć naturę wszechświata?”. Wprawdzie dzisiejsze nauki przyrodnicze opisują świat i jego funkcjonowanie w sposób o wiele bardziej szczegółowy niż tysiące lat temu, stwarzając nieraz wrażenie, że rozumiemy naturę wielu zjawisk, to jednak dalecy jesteśmy od pojęcia natury wszechświata. Dlatego chciałbym zacytować dalszą część wypowiedzi rabina Huny: „Jeśli ktoś ci powie, że zrozumiał naturę wszechświata, odpowiedz mu: czegoż jeszcze dokonać może człowiek, który nastapi po królu, nad

\footnotetext{
${ }^{62}$ Por. Freedman and Simon (eds.), Midrash Rabbah..., s. 78.

${ }^{63}$ Por. np. modlitewnik hebrajski: Polonski (ed.), Sidur..., s. 517.

${ }^{64}$ Por. Polonski (ed.), Sidur..., s. 471.
} 
to, czego on już dokonat?, czyli nad to, czego dokonał Król, Pan Wszechświata (Koh 2,12)" ${ }^{65} \mathrm{~W}$ rzeczywistości bowiem, nawet jeśli pojmiemy, jak otaczający nas świat został urządzony, i tak nie będziemy w stanie zbudować nawet niewielkiego mini-wszechświata.

Traktat Be-reszit Raba stanowi, jak się wydaje, ciekawe źródło informacji o myśli rabinicznej, zbliżonej do myśli filozoficznej, zawierającej refleksje nad początkiem świata. Tekst Pięcioksięgu był traktowany przez autorów wypowiedzi umieszczonych w traktacie jako niepodważalne źródło informacji pochodzącej bezpośrednio od Boga, choć przekazanej w sposób niejednoznaczny, dopuszczający wiele interpretacji. Przeprowadzona analiza wskazuje na sensowność wielu refleksji rabinicznych nawet w świetle dzisiejszej wiedzy naukowej o świecie i jego początkach.

Mirosław Rucki i Michat Prończuk

\section{Bibliografia}

Bacher Wilhelm and Broydé Isaac, „Phinehas Ben Jair”, w: Singer, Vizetelly, and FunK (eds.), The Jewish Encyclopedia..., http://www.jewishencyclopedia.com/articles/12121phinehas-ben-jair (26.06.2017).

Bacher Wilhelm and Ochser Schulim, „Samuel Ben Ammi”, w: Singer, Vizetelly, and FunK (eds.), The Jewish Encyclopedia..., http://www.jewishencyclopedia.com/articles/13 091-samuel-ben-ammi (26.06.2017).

„Bar Kappara”, w: Singer, Vizetelly, and FunK (eds.), The Jewish Encyclopedia..., http://www.jewishencyclopedia.com/articles/13703-simeon-bar-kappara (26.06.2017).

BorzymińsKa Zofia, ,Midrasz Raba”, w: Polski Słownik Judaistyczny, http://www.jhi.pl/ psj/Midrasz_Raba (17.06.2017).

De Morgan Augustus, A Budget of Paradoxes, The Open Court Publishing Co., Chicago/London 1915.

DŁugosz-Kurczabowa Krystyna, Wielki słownik etymologiczno-historyczny języka polskiego, PWN, Warszawa 2008.

Edwards Rem, What Caused the Big Bang?, Brill, Amsterdam — New York 2001.

Freedman Harry and Simon Maurice (eds.), Midrash Rabbah, vol. 1, The Soncino Press, London 1961.

\footnotetext{
${ }^{65}$ FreEdman and Simon (eds.), Midrash Rabbah..., s. 87.
} 
„Hama b. Hanina”, w: Singer, Vizetelly, and Funk (eds.), The Jewish Encyclopedia..., http://www.jewishencyclopedia.com/articles/7119-hama-b-hanina (26.06.2017).

Hawking Stephen, „The Origin of the Universe”, http://www.hawking.org.uk/the-origin-ofthe-universe.html (29.04.2017).

HAwKING Stephen, „The Beginning of Time”, http://www.hawking.org.uk/the-beginning-oftime.html (29.04.2017).

http://beta.hebrewbooks.org/11574 (22.06.2017).

http://www.daat.co.il/daat/tanach/raba1/1.htm (22.06.2017).

JacoBs Joseph and Lauterbach Jacob Zallel, „Zugot”, w: Singer, Vizetelly, and FunK (eds.), The Jewish Encyclopedia..., http://www.jewishencyclopedia.com/articles/15293zugot (26.06.2017).

JASTROw Marcus, A Dictionary of the Targumim, the Talmud Babli and Yerushalmi, and the Midrashic Literature, vol. 2, Luzac \& Co, London 1903.

Jastrow Marcus and Mendelsohn S., „Berechiah I”, w: Singer, Vizetelly, and Funk (eds.), The Jewish Encyclopedia..., http://www.jewishencyclopedia.com/articles/3036-berechiah -i-r (26.06.2017).

Koehler Ludwik, Baumgartner Walter i StAmm Johann Jakub, Wielki słownik hebrajskopolski i aramejsko-polski Starego Testamentu, t. 2, Vocatio, Warszawa 2008.

Kolb Bryan i Whishaw Ian Q., Fundamentals of Human Neuropsychology, Freeman and Company, New York 1996.

Konstytucja dogmatyczna o Objawieniu Bożym DEI VERBUM, http://tiny.pl/g1nkd (26.06.2017).

Lisowsky Gerhard (Hg.), Konkordanz zum Hebräischen Alten Testament, Deutsche Bibelgesselschaft, Stuttgart 1993.

Mielziner Moses, „Amora”, w: Singer, Vizetelly, and Funk (eds.), The Jewish Encyclopedia..., http://www.jewishencyclopedia.com/articles/1421-amora (29.04.2017).

„Moses Ben Nahman Gerondi”, w: Singer, Vizetelly, and Funk (eds.), The Jewish Encyclopedia..., http://www.jewishencyclopedia.com/articles/11284-nahmanides-moses (26.06. 2017).

Penrose Roger, Droga do rzeczywistości. Wyczerpujący przewodnik o prawach rządzących Wszechświatem, przeł. Jerzy Przystawa, Prószyński i S-ka, Warszawa 2006.

Platon, Dialogi, przeł. Władysław Witwicki, Tower Press, Gdańsk 2000.

Platon, Państwo, przeł. Władysław Witwicki, Wydawnictwo ANTYK, Kęty 2003.

Polonski Pinchas (ed.), Sidur szaarej tfila, Machanaim, Jerusalem 2008. 
Pорко Maciej, „Wschód starożytny a początki myśli europejskiej”, Przegląd Orientalistyczny 1999, nr 1-2 (189-190), s. 15-25.

„Rabbi Dr. Isidore Epstein, B.A., Ph.D., D.Lit., 1894-1962”, Transactions (Jewish Historical Society of England) 1962-1967, vol. 21, s. 327-336.

RIENECKer Fritz i MaIer Gerhard, Leksykon biblijny, przeł. Danuta Irmińska, Vocatio, Warszawa 2001.

RuCKi Mirosław, „Sześć dni stworzenia - Heksaemeron”, Teologia i Człowiek 2016, nr 1 (33), s. 85-105.

Schechter Solomon and Mendelsohn S., „Jonah”, w: Singer, Vizetelly, and Funk (eds.), The Jewish Encyclopedia..., http://www.jewishencyclopedia.com/articles/8752-jonah (26.06.2017).

Schechter Solomon and Mendelsohn S., „Levi II”, w: Singer, Vizetelly, and Funk (eds.), The Jewish Encyclopedia..., http://www.jewishencyclopedia.com/articles/9803-levi-ii (26.06.2017)

Scholem Gershom, Mistycyzm żydowski i jego główne kierunki, przeł. Ireneusz Kania, Wydawnictwo Aletheia, Warszawa 2007.

SCHROEDER Gerald, „Age of the Universe”, http://www.aish.com/societywork/sciencenature/ Age_of the_Universe.asp (29.04.2017).

Singer Isidore and Broydé Isaac, „Huna Bar Abbin Ha-Kohen”, w: Singer, Vizetelly, and FunK (eds.), The Jewish Encyclopedia..., http://www.jewishencyclopedia.com/articles/79 33-huna-bar-abbin-ha-kohen (17.06.2017).

Singer Isidore and Lauterbach Jacob Zallel, „Judah Ben Ilai”, w: Singer, Vizetelly, and Funk (eds.), The Jewish Encyclopedia..., http://www.jewishencyclopedia.com/articles/89 94-judah-ben-ilai (26.06.2017).

Singer Isidore, Vizetelly Frank, and Funk Isaac (eds.), The Jewish Encyclopedia, vol. 112, Funk \& Wagnals Co., New York — London 1901-1906.

Sumber Jonathan, On the Nature and Origin of Time, Space, Gravity and Reality, Outskirts Press, Denver 2016.

„Tannaim and amoraim”, w: Singer, Vizetelly, and Funk (eds.), The Jewish Encyclopedia..., http://www.jewishencyclopedia.com/articles/14240-tannaim-and-amoraim (17.06. 2017).

TATARKIEWICZ Władysław, Historia filozofii, t. I, PWN, Warszawa 1978.

TrePPA Zbigniew, Fotografia z Manopello. Twarz Zmartwychwstającego Mesjasza, Wydawnictwo Duszpasterstwa Rolników, Włocławek 2009.

Turek Przemysław, Od Gilgamesza do kasydy. Poezja semicka w oryginale i w przekładzie, Księgarnia Akademicka, Kraków 2010. 
VIDAs Moulie, Tradition and the Formation of the Talmud, Princeton University Press, Princeton 2014.

WoLEŃSKi Jan, Epistemologia, PWN, Warszawa 2005.

Zавоєотму Andrzej, „Naturalizm metodologiczny w nauce - dylemat teisty”, Filozoficzne Aspekty Genezy 2016, t. 13, s. 25-48.

\section{Refleksja nad początkami wszechświata w traktacie Be-reszit Raba}

\section{Streszczenie}

Z punktu widzenia dzisiejszej metodologii naukowej Biblia nie stanowi źródła wiedzy naukowej, przynajmniej w zakresie nauk przyrodniczych. Przez wiele wieków teksty Biblii były jednak źródłem refleksji, w tym filozoficznej, nad początkiem istnienia wszechrzeczy. Przykładem takiej refleksji jest traktat Midrasz Raba zawierający komentarze do Księgi Rodzaju. I choć rozważania rabiniczne mają raczej charakter praktyczny (są ukierunkowane na wypełnianie przepisów Prawa Mojżeszowego), to często odwołują się do pytań egzystencjalnych i filozoficznych. Jest to szczególnie zauważalne w przytaczanych $\mathrm{w}$ traktacie dyskusjach z filozofami greckimi. Przeprowadzona analiza wskazuje na sensowność wielu refleksji rabinicznych, nawet w świetle dzisiejszej wiedzy naukowej o świecie i jego początkach, mimo że rabini nie odwoływali się do wiedzy przyrodniczej, a bazowali wyłącznie na tekstach biblijnych.

Słowa kluczowe: midrasz, judaizm, Księga Rodzaju, początek, stworzenie.

\section{Reflection on the Beginning of the Universe in the Treatise Bereshit Rabbah}

\section{Summary}

From the perspective of today's scientific methodology, the Bible does not count as a scientific source, at least as far as the natural sciences are concerned. However, for many centuries biblical texts have inspired reflections - including those of a philosophical kind on the beginning of the existence of all things. The treatise Midrash Rabbah, with its commentary on the Book of Genesis, is an example of such reflections. In spite of the fact that rabbinic interpretation focuses on practical aspects of the Mosaic Law, it often raises philosophical and existential questions, especially in the context of those discussions that involve the gentile philosophers referred to in the treatise. The analysis undertaken here seeks to highlight those rabbinic reflections that appear reasonable even from the perspective of modern science aimed at describing the world and its origin - even though the rabbis were not themselves engaged in any form of the natural sciences and based their reflections exclusively on biblical texts.

Keywords: midrash, Judaism, the Book of Genesis, the beginning, creation. 